\title{
COMPRESSIVE STRENGTH PROPERTIES OF SNOW
}

\author{
By H. H. G. JellineK* \\ (U.S. Army Snow, Ice and Permafrost Research Establishment, Corps of Engineers, \\ Wilmette, Illinois, U.S.A.)
}

\begin{abstract}
The compressive strength of snow cylinders was investigated as a function of the age of the snow from which the cylinders were made, the snow particle size and the age of the cylinders. The results show that the compressive strength is reduced if the snow is older, if the particle size is smaller, or if the cylinders are younger. The variation with age of the cylinders can be represented by an equation similar to that for a first-order chemical reaction. The effect of adding small quantities of various gases to the atmosphere in which the cylinders were kept was also investigated; carbon dioxide and methane had no measurable effect, but ammonia lowered the strength of the cylinders. All the strength measurements were carried
out at $-10^{\circ} \mathrm{C}$.

Zusammenfassung. Es handelt sich um die Untersuchung der Druckfestigkeit von Schneezylindern als Funktion des Alters vom Schnee, aus dem die Zylinder gemacht waren, der Teilchengrösse des Schnees und des Alters der Zylinder. Die Resultate erwiesen, dass bei älterem Schnee, bei kleinerer Teilchengrösse, oder wenn die Zylinder jünger sind, die Druckfestigkeit reduziert wird. Die Schwankung mit dem Alter der Zylinder lässt sich durch eine Gleichung ähnlich der Gleichung einer chemischen Reaktion erster Ordnung wiedergeben. Ausserdem wurde untersucht, wie sich der Zusatz kleiner Mengen verschiedener Gase zur Atmosphäre, in der die Zylinder gehalten wurden, auswirkte; Kohlensäure und Methan hatten keine messbare Wirkung, aber Ammoniak reduzierte die Festigkeit der Zylinder. Alle Festigkeitsmessungen wurden bei einer Temperatur von $-10^{\circ} \mathrm{C}$ ausgeführt.
\end{abstract}

\section{INTRODUCTION}

Extensive studies of the strength properties of snow were made by Butkovich, ${ }^{\mathbf{T}}$ who investigated the compressive, tensile, shear and torsional strengths of snow as a function of density. A very pronounced dependence of the strength on the density was found which could be expressed in a general formula. The work of disaggregation as a function of density was also reported by Butkovich, who also gives relevant literature references. Bender ${ }^{2}$ has also studied the age hardening of snow by measuring the work of disaggregation. In the present work a beginning has been made of a study of the uniaxial compressive strength of snow cylinders as a function of age and of particle size of snow fractions. Ageing of snow and the effect on the compressive strength of snow of the inclusion of various gases in the atmosphere in which they were kept, were also investigated.

\section{Experimental Details}

Materials. Two different snows were used for the experiments. One snow was collected at Wilmette, and stored at $-20^{\circ}$ C.; experiments were started after about two weeks; the other was collected at Houghton, Michigan, stored at about $-15^{\circ} \mathrm{C}$. for about four weeks prior to use and subsequently stored at $-20^{\circ} \mathrm{C}$.

Preparation of Snow Fractions. The snow fractions were prepared on a "Ro-Tap" shaker; the sieves used were of the U.S. standard sieve series. The snow for each of the Houghton snow fractions was obtained after two minutes shaking, whereas the Wilmette snow fractions were obtained after longer periods of shaking, especially for the small size and largest size of particles.

Apparatus and Technique. All strength measurements were carried out at $-10^{\circ} \pm 0.5^{\circ} \mathrm{C}$. with a Carver Hydraulic Laboratory Press in conjunction with a Baldwin Load Cell (2000 lb., 900 kg.) and a Leeds and Northrup recorder. A picture of this press is shown in a report by Butkovich on the Ultimate Strength of Ice. ${ }^{3}$

The snow cylinders were prepared at $-20^{\circ} \mathrm{C}$. in a Lucite cylinder of $4.3^{8} \mathrm{~cm}$. inside diameter and $25 \mathrm{~cm}$. high. The height was graduated and could easily be read to the nearest $\mathrm{mm}$. About $82.5 \mathrm{gm}$. of snow were weighed into the tube with an accuracy of $0.1 \mathrm{gm}$. The snow was then compressed to a height of $10 \mathrm{~cm}$. in the plastic tube with the press to which a

* Present address: Applied Science Research Laboratory, University of Cincinnati, Cincinnati 21, Ohio. 
suitable piston was attached. Actually only half the compression was carried out at a time, the cylinder was then inverted and the compression completed. Thus large density gradients in the cylinders were avoided. The majority of densities were in the range from 0.548 to $0.55^{2} \mathrm{gm} . / \mathrm{cm} .{ }^{3}$. The snow cylinders (diameter $4.3^{8} \mathrm{~cm}$., height $10 \mathrm{~cm}$.) were then removed to a cold room of $-10^{\circ} \mathrm{C}$. and crushed after a time interval as indicated in the experimental results.

\section{Experimental Results}

Ageing of Snow Cylinders. The ageing of snow cylinders was investigated using the unfractionated, original snow samples, except that the Houghton snow was passed through a I. I9 mm. sieve to remove lumps. Tables I and II and Figs. I and 2 show the experimental results for the Wilmette snow. Table III and Fig. 3 show the results for the Houghton snow.

Table I. Compressive Strength as a Function of Ageing of Snow Cylinders at $-10^{\circ} \mathrm{C}$. Wilmette Snow unfractionated

$\begin{array}{cc}\begin{array}{c}\text { Age of snow } \\ \text { days }\end{array} & \begin{array}{c}\text { Age of cylinders } \\ \text { hours }\end{array} \\ 43 & \text { c. } 0 \cdot 1 \\ 45 & 7 \cdot 1 \\ 50 & 22 \cdot 7 \\ 35 & 28 \cdot 7 \\ 42 & 69 \cdot 0 \\ 45 & 92 \cdot 4 \\ 37 & 117 \cdot 9 \\ 36 & 167 \cdot 3 \\ 43 & 212 \cdot 5\end{array}$
Age of snow: $35-50$ days

$\begin{array}{ccc}\begin{array}{c}\text { Mean } \\ \text { compressive strength } \\ \mathrm{kg} / / \mathrm{cm} .^{2}\end{array} & \begin{array}{c}\text { Standard } \\ \text { deviation } \\ \mathrm{kg} . / \mathrm{cm} .^{2}\end{array} & \begin{array}{c}\text { Standard } \\ \text { error of mean } \\ \mathrm{kg} . / \mathrm{cm}^{2}\end{array} \\ 4.9 & \pm 0.6 & \pm 0.2 \\ 6.7 & \pm 1.1 & \pm 0.3 \\ 10.6 & \pm 1 \cdot 2 & \pm 0.4 \\ 9.6 & \pm 2.0 & \pm 0.6 \\ 10.9 & \pm 1.5 & \pm 0.4 \\ 13.5 & \pm 2.5 & \pm 0.7 \\ 15.9 & \pm 1.4 & \pm 0.4 \\ 11.0 & \pm 1.7 & \pm 0.5 \\ & \pm 1.4 & \pm 0.4\end{array}$

Table II. Compressive Strength as a Function of Ageing of Snow Cylinders at $-10^{\circ} \mathrm{C}$.

\begin{tabular}{|c|c|c|c|}
\hline \multirow{3}{*}{$\begin{array}{c}\text { Age of cylinders } \\
\text { hours }\end{array}$} & \multicolumn{2}{|c|}{$\begin{array}{l}\text { Wilmette snow unfractionated } \\
\text { Age of snow: } 57 \text { days }\end{array}$} & \multirow{3}{*}{$\begin{array}{l}\text { Standard } \\
\text { error of mean } \\
\text { kg. } / \mathrm{cm} .^{2}\end{array}$} \\
\hline & $\begin{array}{c}\text { Mean } \\
\text { compressive strength }\end{array}$ & $\begin{array}{l}\text { Standard } \\
\text { deviation } \\
\mathrm{kg} / \mathrm{cm}^{2}\end{array}$ & \\
\hline & $\mathrm{kg} \cdot / \mathrm{cm} \cdot{ }^{2}$ & $\begin{array}{l}\mathrm{kg} . / \mathrm{cm} . \\
+0.5\end{array}$ & \\
\hline $\begin{array}{l}0.05 \\
4.6\end{array}$ & $\begin{array}{l}1.0 \\
3 \cdot 6\end{array}$ & $\begin{array}{l} \pm 0.5 \\
\pm 0.8\end{array}$ & $\pm 0 \cdot 2$ \\
\hline $\begin{array}{r}4.7 \\
23 \cdot 7\end{array}$ & $7 \cdot 1$ & $\pm \mathrm{I} \cdot 6$ & $\pm 0 \cdot 5$ \\
\hline $29 \cdot 14$ & $7 \cdot 7$ & $\pm \mathbf{r} \cdot 3$ & $\pm 0 \cdot 4$ \\
\hline & $8 \cdot 0$ & $\pm 0 \cdot 9$ & $\pm 0 \cdot 3$ \\
\hline 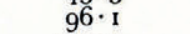 & $8 \cdot 8$ & $\pm \mathrm{r} \cdot 3$ & \pm 0.4 \\
\hline 139.5 & $7 \cdot 5$ & $\pm \mathbf{I} \cdot \mathbf{I}$ & $\pm 0 \cdot 3$ \\
\hline $36 \cdot 4$ & $9 \cdot 0$ & $\pm \mathbf{r} \cdot 5$ & \\
\hline
\end{tabular}

Table III. Compressive Strength as a Function of Ageing of Snow Cylinders at $-10^{\circ} \mathrm{C}$.

\begin{tabular}{|c|c|c|c|}
\hline \multirow{5}{*}{$\begin{array}{c}\text { Age of cylinders } \\
\text { hours }\end{array}$} & \multirow{2}{*}{\multicolumn{2}{|c|}{$\begin{array}{l}\text { Houghton snow } \\
\text { Age of snow: } 30 \text { days }\end{array}$}} & \multirow{4}{*}{$\begin{array}{c}\text { Standard } \\
\text { error of mean } \\
\mathrm{kg} . / \mathrm{cm} .^{2}\end{array}$} \\
\hline & & & \\
\hline & $\begin{array}{c}\text { Mean } \\
\text { compressive strength }\end{array}$ & $\begin{array}{l}\text { Standard } \\
\text { deviation }\end{array}$ & \\
\hline & $\mathrm{kg} . / \mathrm{cm} .^{2}$ & kg. $/ \mathrm{cm}^{2}{ }^{2}$ & \\
\hline & $\mathrm{I} \cdot 5$ & \pm 0.9 & $\pm 0 \cdot 3$ \\
\hline $5 \cdot 9$ & $3 \cdot 9$ & $\pm 0 \cdot 7$ & $\begin{array}{l} \pm 0 \cdot 2 \\
\pm 0 \cdot 4\end{array}$ \\
\hline $21 \cdot 7$ & $5^{\cdot} \cdot 1$ & $\pm 1 \cdot 4$ & $\begin{array}{l} \pm 0.4 \\
+0.5\end{array}$ \\
\hline $45 \cdot 7$ & $\begin{array}{l}8 \cdot 5 \\
8 \cdot 3\end{array}$ & $\begin{array}{l} \pm \mathbf{I} \cdot 5 \\
\pm \mathbf{I} \cdot \mathbf{I}\end{array}$ & \pm 0.3 \\
\hline & $9 \cdot 9$ & $\pm 1 \cdot 2$ & \pm 0.4 \\
\hline $166 \cdot 7$ & 10.6 & $\pm 2 \cdot 7$ & \pm 0.9 \\
\hline
\end{tabular}

The cylinders fractured usually into three pieces in a similar way to that observed by Butkovich (see Fig. I of Butkovich's report ${ }^{\mathrm{I}}$ ). The number near each of the experimental points in Fig. I gives the age of the snow in days from which the twelve cylinders, whose mean strength the points represent, were made. It is seen that the younger the snow, the greater the strength of the cylinders. The cylinders from the Wilmette snow represented in 


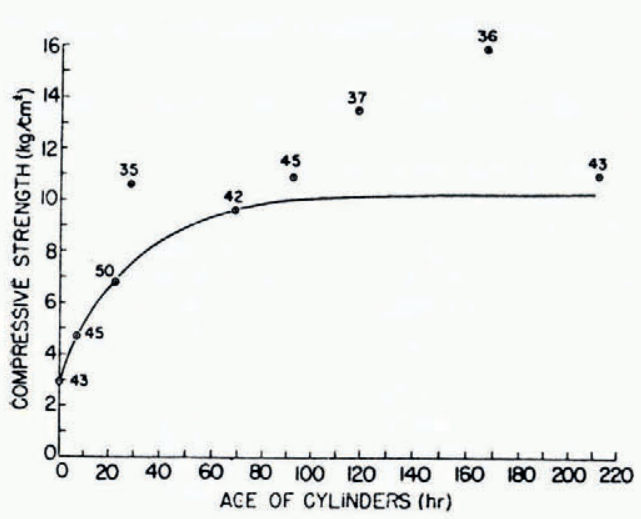

Fig. $I$

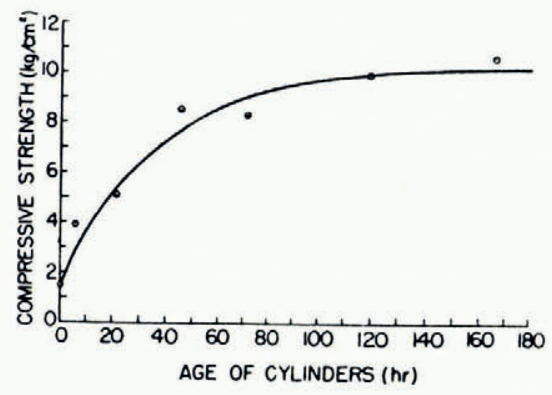

Fig. 3

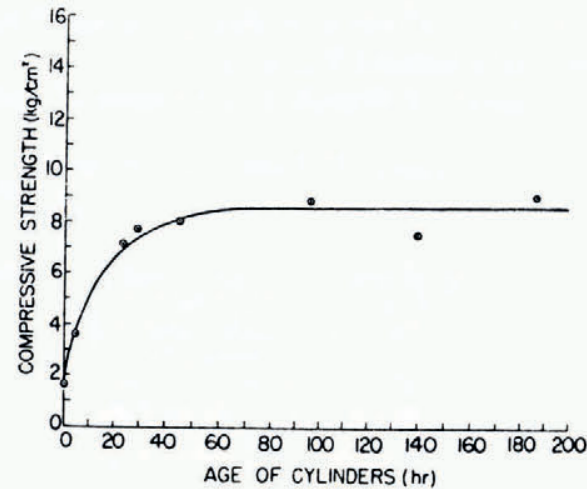

Fig. 2

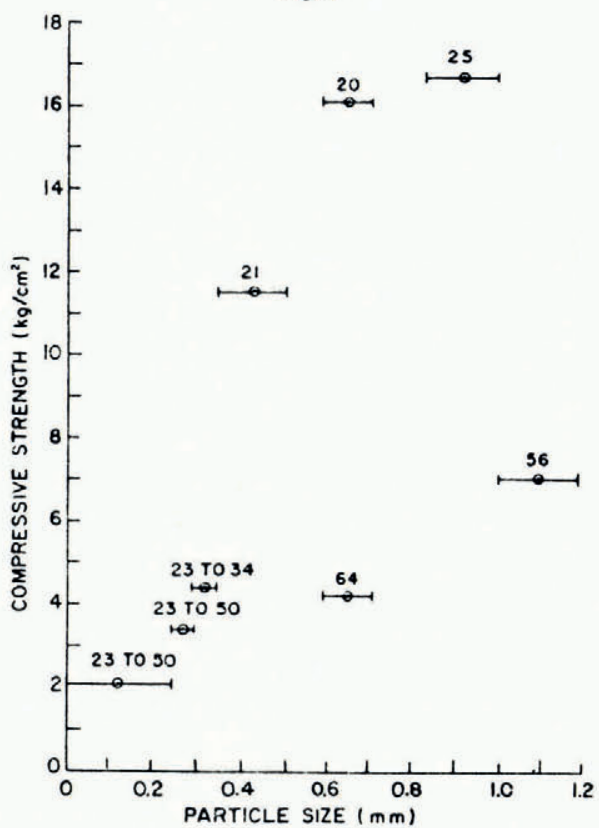

Fig. 4

Fig. I. Compressive strength of snow cylinders (radius $2.19 \mathrm{~cm}$., height $10 \mathrm{~cm}$., density c. $0.550 \mathrm{gm} . / \mathrm{cm} .3$ ) as a function of the age of the cylinders at $-10^{\circ} \mathrm{C}$. Each point represents the average of twelve tests. The numbers near the points represent the age in days of the snow from which the cylinder was made. Snow was collected at Wilmette, Illinois. Curve was calculated from equation ( $\mathrm{r} a$ ) with the following constants:

$$
S_{0}=2.8 \mathrm{~kg} . / \mathrm{cm}^{2}, S_{f}=10.3 \mathrm{~kg} . / \mathrm{cm}^{2}, \mathrm{k}=3.52 \times \mathrm{ro}^{-2} \mathrm{hr} .^{-1}
$$

Fig. 2. Compressive strength of snow cylinders (radius $2.19 \mathrm{~cm}$., height $10 \mathrm{~cm}$., density c. $0.550 \mathrm{gm} . / \mathrm{cm} .3$ ) as a function of the age of the cylinders at $-10^{\circ} \mathrm{C}$. Each point represents the average of twelve tests. The age of the snow when preparing cylinders was in all cases 57 days. Snow was the same (Wilmette) as that for Fig. I. Curve was calculated from equation (1a) with the following constants:

$$
S_{0}=1.5 \mathrm{~kg} . / \mathrm{cm} .^{2}, S_{f}=8.6 \mathrm{~kg} . / \mathrm{cm} .^{2}, k=6.45 \times 10^{-2} \mathrm{hr} .^{-1}
$$

Fig. 3. Compressive strength of snow cylinders (radius $2.19 \mathrm{~cm}$., height $10 \mathrm{~cm}$., density c. $0.550 \mathrm{gm} . / \mathrm{cm} .3$ ) as a function of the age of the cylinders at $-10^{\circ} \mathrm{C}$. Each point represents the average of ten tests. The age of the snow when preparing cylinders was in all cases 28 days. Snow was collected at Houghton, Michigan. Curve was calculated from equation (ra) with the following constants:

$$
S_{0}=1.5 \mathrm{~kg} . / \mathrm{cm} .^{2}, S_{f}=10.3 \mathrm{~kg} . / \mathrm{cm} .^{2}, k=2.70 \times 10^{-2} \mathrm{hr} .^{-1}
$$

Fig. 4. Compressive strength of snow cylinders as a function of snow particle size $\left(-10^{\circ} \mathrm{C}\right.$.). The horizontal lines represent the range of sieve sizes used to obtain the particular fraction. Each point represents the average of twelve tests. The number beside each point gives the age of the snow (Wilmette snow). Each cylinder was aged for $168 \mathrm{hr}$. at $-10^{\circ} \mathrm{C}$. 
Fig. 2 were all made within 30 hours of each other, as were the cylinders from the Houghton snow represented in Fig. 3 .

Compressive Strength as a Function of Particle Size. Table IV gives the compressive strength

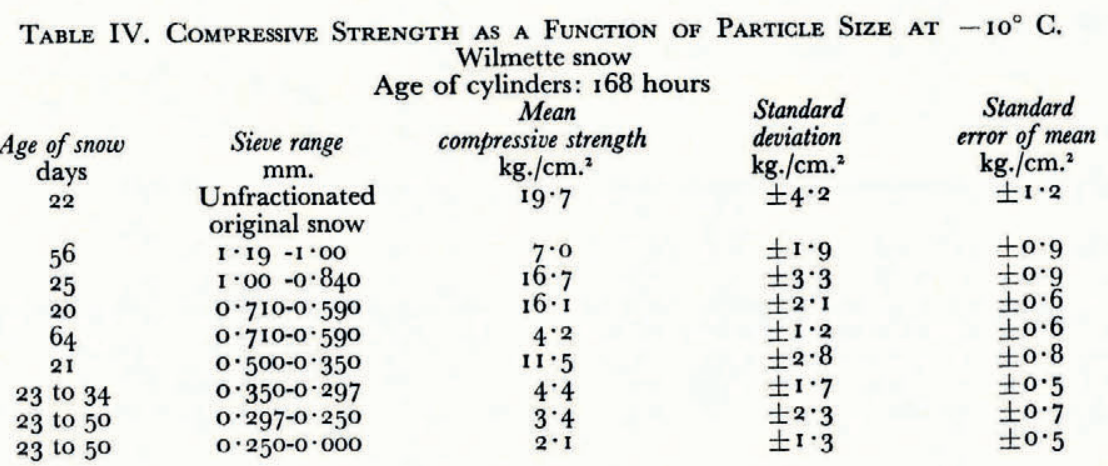

values as a function of particle size, and Fig. 4 shows the mean strength values as a function of particle size for the Wilmette snow. Most of the Wilmette snow (c. 50 per cent.) was in the size range from 3.5 to $5.0 \mathrm{~mm}$. There is a very appreciable decrease of strength with particle size. Fig. 4 shows again the marked influence of the age of the snow. It was desired at a later date to determine the strength of the snow fraction of large particle size. 'These later strength values for the older snow were very much lower (see Table IV and Fig. 4, 56 days) than expected from the previous results. In order to check this behavior, tests were repeated on a snow fraction which had been investigated about six weeks earlier. This means that cylinders were prepared of snow six weeks older than that used for the previous fraction. The results (Table IV and Fig. 4, 64 days) show that the strength of the cylinders is very dependent on the age of the snow. This strong dependence is also apparent for the three fractions of small particle size. These measurements were made before the importance of age was realized. For this reason the average strength values for the smaller size fractions are considered to be too small compared with those of the larger size fractions of Table IV.

An interesting by-product of this work is given by the densities of the snow fractions before compacting. These densities were obtained by pouring the fractions loosely into the plastic cylinder without compacting. Fig. 5 shows the results. A decrease of density with increasing particle size is observed.

Because of the strong influence of the age of snow on its strength, a series of experiments were carried out with the Houghton snow on the strength as a function of particle size, all cylinders being prepared within 30 hours of each other.

These results are shown in Table $\mathrm{V}$ and Fig. 6. Here again the compressive strength

Table V. Compressive Strength as a Function of Particle Size at $-10^{\circ} \mathrm{C}$. Houghton snow

Age of snow: 27 to 28 days

Age of cylinders: 168 hours

Sieve range

$\mathrm{mm}$.

Original,

unfractionated snow

$1 \cdot 00-0.840$

$0.840-0.710$

0.7 10-0.590

$0.590-0.500$

$0 \cdot 500-0 \cdot 350$

$0.350-0.250$

$0.250-0.074$

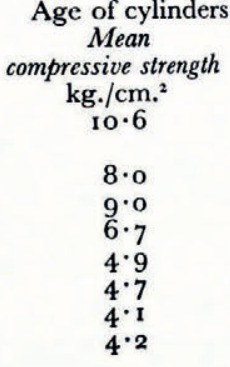

\begin{tabular}{|c|c|}
\hline $\begin{array}{l}\text { Standard } \\
\text { deviation } \\
\mathrm{kg} \cdot / \mathrm{cm}^{2} \\
\pm 2 \cdot 7\end{array}$ & $\begin{array}{l}\text { Standard } \\
\text { error of mean } \\
\mathrm{kg} . / \mathrm{cm}^{2} \\
\pm 0.9\end{array}$ \\
\hline $\begin{array}{l} \pm 2 \cdot 0 \\
\pm 0 \cdot 8 \\
\pm 1 \cdot 2 \\
\pm 1 \cdot 3 \\
\pm 1 \cdot 1 \\
\pm 1 \cdot I\end{array}$ & $\begin{array}{l} \pm 0.6 \\
\pm 0.3 \\
\pm 0.4 \\
\pm 0.4 \\
\pm 0.5 \\
\pm 0.3\end{array}$ \\
\hline
\end{tabular}




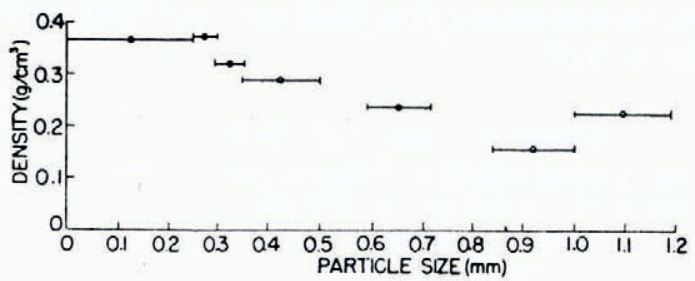

Fig. 5 (left). Density obtained by loosely packing snow fractions $\left(-20^{\circ} \mathrm{C}\right.$.). (Wilmette snow)

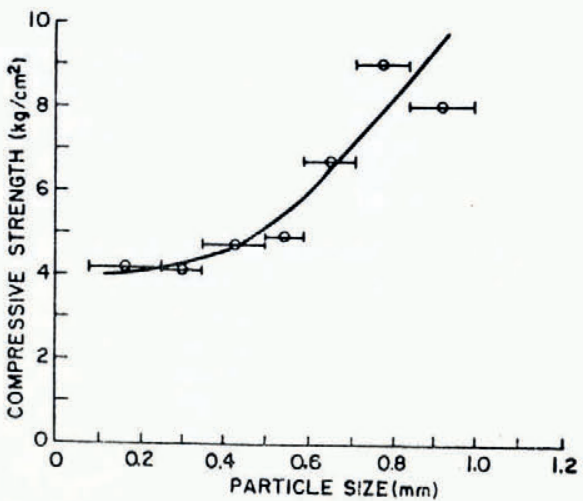

decreases with particle size, however not quite as drastically as for the Wilmette snow. The difference is due to the high age of the lower Wilmette fractions as pointed out previously.

Mixture of Fractions. A number of experiments were also carried out on the strength of mixtures of fractions of the Wilmette Snow. On the whole these results reflect those which were found with single fractions. The results are given in Table VI.

Table Vi. Compressive Strength of Mixtures of Fractions at $-10^{\circ} \mathrm{C}$. Wilmette snow

\section{Composition of fraction}

Fraction $\mathrm{I} \cdot \mathrm{oo} \mathrm{mm} \cdot-\mathrm{0} \cdot 840 \mathrm{~mm}$. plus fraction $0.710 \mathrm{~mm} .-0.590 \mathrm{~mm}$. plus fraction $0.500 \mathrm{~mm} .-0.350 \mathrm{~mm}$. I : I : I by weight. Age of snow $7 \mathrm{r}$ days $\quad \ldots \quad \ldots \quad \ldots$

Fraction $0.710 \mathrm{~mm} .-0.590 \mathrm{~mm}$. plus fraction $0.500 \mathrm{~mm} \cdot-0.350 \mathrm{~mm}$. plus fraction $0 \cdot 350 \mathrm{~mm} .-0 \cdot 297 \mathrm{~mm}$. I : I : I by weight. Age of snow 63 days $\quad \ldots \quad \ldots \quad \ldots$

Fraction $0.500 \mathrm{~mm} .-0.350 \mathrm{~mm}$. plus fraction $0.350 \mathrm{~mm} .-0.297 \mathrm{~mm}$. plus $0.250 \mathrm{~mm}$.o mm. I : I : I by weight. Age of snow 66 days $\quad . \quad 6 \quad \ldots \quad \ldots \quad \ldots \quad \ldots$

3 parts of weight of fraction $\mathrm{I} \cdot \mathrm{Oo} \mathrm{mm}$. to $0.71 \mathrm{~mm}$. plus I part of fraction $0.35 \mathrm{~mm}$. to o $\mathrm{mm}$. Age of snow 79 days .. ..

I 9 parts by weight of fraction $0.840 \mathrm{~mm}$. to $0.710 \mathrm{~mm}$. plus $\mathrm{I}$ part of fraction $0.074 \mathrm{~mm}$. to $0 \mathrm{~mm}$. Age of snow 89 days

Fraction $0.840 \mathrm{~mm}$ to $0.710 \mathrm{~mm}$. alone

\section{Mean \\ compressive strength}

$\mathrm{kg} . / \mathrm{cm} .^{2}$

$5 \cdot 4$

$3 \cdot 4$

$\mathbf{I} \cdot 05$

$3 \cdot 2$

$2 \cdot 7$

$2 \cdot 7$
Influence of Gases on the Compressive Strength of Snow

\section{Standard}

deviation

$\mathrm{kg} \cdot / \mathrm{cm} .^{2}$

$\pm 1 \cdot 9$

$\pm 0.5$

A number of snow cylinders were prepared which were exposed to gases such as carbon dioxide $\left(\mathrm{CO}_{2}\right)$, methane $\left(\mathrm{CH}_{4}\right)$ and ammonia $\left(\mathrm{NH}_{3}\right)$. Other cylinders were prepared at the 
same time for comparison and treated in the same way except that they were not exposed to the gases. These are referred to as blanks in Table VII.

Table ViI. Effect of Gases on the Compressive Strength of Snow

(a) Original Wilmette Snow treated with $\mathrm{NH}_{3}$ before making cylinders. Cylinders aged for 168 hours at $-10^{\circ} \mathrm{C}$. before breaking. No evacuation. Samples smelled of $\mathrm{NH}_{3}$ at the time of breaking.

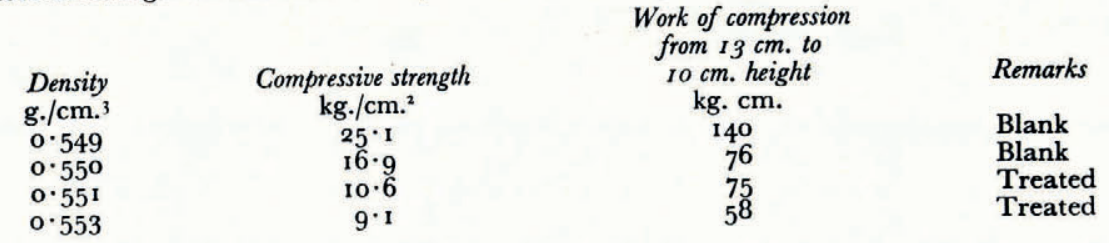

(b) Original Wilmette Snow. Cylinders treated with $\mathrm{NH}_{3}$. Cylinders stood in the open for 3 hours at $-20^{\circ} \mathrm{C}$. Scarcely a smell of $\mathrm{NH}_{3}$ left. Then aged for 168 hours at $-10^{\circ} \mathrm{C}$. before breaking.

$\begin{array}{lcc}\begin{array}{l}\text { Density } \\ \text { g./cm. }\end{array} & \begin{array}{r}\text { Compressive strength } \\ \text { kg./cm. }\end{array} & \text { Remarks } \\ 0 \cdot 547 & 8 \cdot 2 & \text { Blank } \\ 0 \cdot 553 & 15 \cdot 1 & \text { Blank } \\ 0 \cdot 550 & 11 \cdot 5 & \text { Blank } \\ 0 \cdot 553 & 14.5 & \text { Blank } \\ 0 \cdot 547 & 10 \cdot 9 & \text { Blank } \\ 0.549 & 10.6 & \text { Blank }\end{array}$

\begin{tabular}{|c|c|}
\hline $\begin{array}{l}\text { Mean } \\
\text { Standard deviation } \\
\text { Standard error of mean }\end{array}$ & $\begin{array}{r}11 \cdot 8 \\
\pm 2 \cdot 6 \\
\pm 1 \cdot 1\end{array}$ \\
\hline $\begin{array}{l}0.549 \\
0.549 \\
0.549 \\
o \cdot 550 \\
o \cdot 548 \\
0.549\end{array}$ & $\begin{array}{l}8 \cdot 8 \\
8 \cdot 8 \\
4 \cdot 5 \\
9 \cdot 4 \\
6 \cdot 7 \\
7 \cdot 6\end{array}$ \\
\hline $\begin{array}{l}\text { Mean } \\
\text { Standard deviation } \\
\text { Standard error of mean }\end{array}$ & $\begin{array}{r}7.6 \\
\pm 1 \cdot 8 \\
\pm 0 \cdot 8\end{array}$ \\
\hline
\end{tabular}

(c) Original Wilmette Snow. Evacuated for $1 \frac{1}{2}$ hours at $-10^{\circ}$ C. after $\mathrm{NH}_{3}$ treatment. Cylinders aged 168 and $33^{6}$ hours, respectively.

\begin{tabular}{|c|c|c|c|c|}
\hline \multirow{2}{*}{$\begin{array}{l}\text { Density } \\
\text { g./cm. }{ }^{3} \\
\text { o. } 5499 \\
0 \cdot 549 \\
0 \cdot 550\end{array}$} & \multirow{2}{*}{$\begin{array}{l}\text { Compressive strength } \\
\text { kg./cm. }{ }^{2} \\
18 \cdot 4 \\
17 \cdot 2 \\
17 \cdot 8\end{array}$} & Blank, aged 168 hours & \multicolumn{2}{|c|}{ Remarks } \\
\hline & & ", & ", & $"$ \\
\hline Mean & $17 \cdot 8$ & \multirow{2}{*}{\multicolumn{3}{|c|}{ Treated, aged 168 hours }} \\
\hline $0.55^{1}$ & 10.9 & & & \\
\hline $\begin{array}{l}0 \cdot 549 \\
0 \cdot 550\end{array}$ & $10 \cdot 6$ & $"$ & " & ", \\
\hline & $11 \cdot 8$ & $"$ & $"$ & $"$ \\
\hline Mean & II $\cdot 1$ & & & \\
\hline $0 \cdot 549$ & $16 \cdot 9$ & \multicolumn{3}{|c|}{ Blank, aged 336 hours } \\
\hline $\begin{array}{l}0 \cdot 549 \\
0.551\end{array}$ & $16 \cdot 9$ & ," & ", & $"$ \\
\hline $0.55^{1}$ & $19 \cdot 4$ & $"$ & " & $"$ \\
\hline Mean & $17 \cdot 7$ & \multirow{2}{*}{\multicolumn{3}{|c|}{ Treated, aged 336 hours }} \\
\hline $0 \cdot 549$ & $10 \cdot 6$ & & & \\
\hline $0 \cdot 549$ & $10 \cdot 9$ & ” & & \\
\hline Mean & $10 \cdot 8$ & & & \\
\hline
\end{tabular}


(d) Original Wilmette Snow. Cylinders after $\mathrm{NH}_{3}$ treatment were compressed in Lucite tubes from $10 \mathrm{~cm}$. to $9 \mathrm{~cm}$. height and then cut to $8 \mathrm{~cm}$. height. Evacuated as before and aged for 168 hours at $-10^{\circ} \mathrm{C}$.

\begin{tabular}{|c|c|c|c|c|}
\hline \multicolumn{2}{|c|}{$\begin{array}{l}\text { Density } \\
\text { g. } / \mathrm{cm} .{ }^{3}\end{array}$} & \multirow[t]{2}{*}{$\begin{array}{c}\text { Compressive strength } \\
\mathrm{kg} \cdot / \mathrm{cm}^{2}\end{array}$} & \multirow[t]{2}{*}{$\begin{array}{c}\text { Compressive work } \\
\text { from } 10 \text { to } 9 \mathrm{~cm} \text {. height } \\
\mathrm{kg} . \mathrm{cm} .\end{array}$} & \multirow[t]{2}{*}{ Remarks } \\
\hline at $10 \mathrm{~cm}$. & at $9 \mathrm{~cm}$. & & & \\
\hline $\begin{array}{l}0.55^{1} \\
0.55^{0}\end{array}$ & 0.607 & $34 \cdot 8$ & 460 & Blank \\
\hline $\begin{array}{l}0.55^{0} \\
0.55^{1}\end{array}$ & 0.606 & $39 \cdot 8$ & 420 & $"$ \\
\hline $\begin{array}{l}0.55^{1} \\
0.549\end{array}$ & 0.607 & $24^{\circ} 0$ & 400 & , \\
\hline $\begin{array}{l}0.549 \\
0.551\end{array}$ & 0.604 & $4 \mathrm{I} \cdot 3$ & $44^{\circ}$ & ", \\
\hline $\begin{array}{l}0.55^{1} \\
0.549\end{array}$ & $\begin{array}{l}0.606 \\
0.605\end{array}$ & $4^{2} \cdot 8$ & 415 & , \\
\hline \multirow{3}{*}{\multicolumn{2}{|c|}{$\begin{array}{l}\text { Mean } \\
\text { Standard deviation } \\
\text { Standard error of mean }\end{array}$}} & 342 & 420 & $"$ \\
\hline & & $\begin{array}{r}36 \cdot 2 \\
+6.0\end{array}$ & 426 & \\
\hline & & $\begin{array}{l} \pm 0.9 \\
\pm 2.9\end{array}$ & & \\
\hline $\begin{array}{l}0.552 \\
0.553\end{array}$ & 0.608 & I1 $\cdot 7$ & 300 & Treated \\
\hline $\begin{array}{l}0.553 \\
0.552\end{array}$ & $\begin{array}{l}0.609 \\
0.608\end{array}$ & $\begin{array}{l}23.7 \\
18.6\end{array}$ & $\begin{array}{l}280 \\
325\end{array}$ & " \\
\hline 0.549 & 0.605 & 19.2 & $\begin{array}{l}325 \\
280\end{array}$ & ", \\
\hline $0.55^{1}$ & 0.607 & 17.4 & 315 & ", \\
\hline $0.55^{\circ}$ & 0.606 & $13 \cdot 2$ & 280 & $"$ \\
\hline \multicolumn{2}{|c|}{$\begin{array}{l}\text { Mean } \\
\text { Standard deviation } \\
\text { Standard error of mean }\end{array}$} & $\begin{array}{r}17 \cdot 3 \\
\pm 4 \cdot 3 \\
\pm 1 \cdot 8\end{array}$ & 297 & \\
\hline
\end{tabular}

(e) Original Wilmette Snow. Cylinders treated with $\mathrm{CO}_{2}$, evacuated and then aged for 168 hours at $-10^{\circ} \mathrm{C}$.

$$
\begin{aligned}
& \text { Density } \\
& \text { g./cm. } \\
& 0.54^{8} \\
& 0.55^{0} \\
& 0.55^{2} \\
& 0.55^{1} \\
& 0.55^{1} \\
& 0.55^{0}
\end{aligned}
$$

Mean

Standard deviation

Standard error of mean

Compressive strength
$\mathrm{kg} . / \mathrm{cm} .^{2}$
11.5
12.1
11.5
13.0
10.3
13.6
12.0
\pm 1.2
\pm 0.5
$0 \cdot 54^{8}$
$0 \cdot 55 \mathrm{I}$
$0 \cdot 55^{\mathrm{I}}$
$0 \cdot 549$
$0.55 \mathrm{I}$
$0 \cdot 5.5 \mathrm{I}$

Mean

Standard deviation

Standard error of mean

Remarks

$$
\begin{array}{r}
13.9 \\
14.5 \\
10.6 \\
11 \cdot 2 \\
9 \cdot 4 \\
11 \cdot 2 \\
11 \cdot 8 \\
\pm 2 \cdot 0 \\
\pm 0.8
\end{array}
$$

Blank

$$
\begin{aligned}
& \text {," } \\
& \text {," }
\end{aligned}
$$$$
\text { , }
$$

Treated

,

,

,9

,

(f) Original Wilmette Snow. Cylinders treated with $\mathrm{CH}_{4}$, evacuated and then aged for 168 hours at $-10^{\circ} \mathrm{C}$.

$$
\begin{aligned}
& \begin{array}{l}
\text { Density } \\
\text { g./cm. }
\end{array} \\
& 0 \cdot 55^{1} \\
& 0 \cdot 54^{8} \\
& 0 \cdot 55^{2}
\end{aligned}
$$

Mean

$$
\begin{aligned}
& o \cdot 55^{2} \\
& o \cdot 55^{0} \\
& o \cdot 55^{2}
\end{aligned}
$$

Mean

Compressive strength
$\mathrm{kg} . / \mathrm{cm}^{2}$
$\mathrm{I} 2 \cdot \mathrm{I}$
$\mathrm{I} 0 \cdot 3$
$10 \cdot 9$

I I $\mathbf{I}$

$10 \cdot 3$

II $\cdot 2$

$10 \cdot 3$

10.6
Remarks

\section{Blank}

,

,

\section{Treated}

," 
The experimental procedure was as follows. The cylinders were made in the usual way at $-20^{\circ} \mathrm{C}$. They were then placed in a wide-necked bottle and exposed to a small amount of gas. The amounts were measured approximately by counting bubbles passed through a washbottle ( 160 bubbles for each experiment, or very approximately roo to $150 \mathrm{ml}$. at N.T.P.). The samples treated with carbon dioxide and methane did not show any difference from the untreated samples, whereas the samples treated with ammonia had a distinctly wet appearance. The untreated and treated samples were then evacuated under a bell jar until the ammonia smell could not be detected any more; the samples treated with the other two gases were evacuated for the same length of time. The cylinders were then stored for 168 hours at $-10^{\circ} \mathrm{C}$. and broken. The results are given in Table VII. It is seen that the strength of the cylinders treated with ammonia has decreased considerably compared with untreated samples, whereas carbon dioxide and methane apparently do not influence the strength.

\section{Discussion}

The ageing curves for the snow cylinders made from the Wilmette and Houghton snows can be fitted very satisfactorily by an equation as follows:

or

$$
\frac{S_{f}-S_{t}}{S_{f}-S_{\mathrm{o}}}=\exp (-k t),
$$

$$
\ln \frac{S_{f}-S_{\mathrm{o}}}{S_{f}-S_{t}}=k t,
$$

where $S_{\circ}$ is the initial and $S_{f}$ the final compressive strength and $k$ a rate constant. The curves in Figs. 1,2 and 3 were calculated with the following constants:

Wilmette Snow (Fig. I) $S_{0}=2.8 \mathrm{~kg} . / \mathrm{cm}^{2}, S_{f}=10.3 \mathrm{~kg} . / \mathrm{cm} .{ }^{2}$.

$$
k=3 \cdot 52 \times 10^{-2} \mathrm{hr}^{-1} \text {. }
$$

Wilmette Snow (Fig. 2) $S_{\mathrm{o}}=\mathrm{I} \cdot 5 \mathrm{~kg} . / \mathrm{cm} .^{2}, S_{f}=8.6 \mathrm{~kg} . / \mathrm{cm} .^{2}$.

$$
k=6 \cdot 45 \times 10^{-2} \mathrm{hr}^{-1} \text {. }
$$

Houghton Snow (Fig. 3) $S_{0}=1 \cdot 5 \mathrm{~kg} \cdot / \mathrm{cm}^{2}, S_{f}=10.3 \mathrm{~kg} \cdot / \mathrm{cm}{ }^{2}$.

$$
k=2 \cdot 70 \times 10^{-2} \mathrm{hr}^{-1} \text {. }
$$

It should be noted that equation ( $\mathrm{ra}$ ) and $(\mathrm{Ib}$ ) is the same as that for a first-order chemical reaction where one compound $\mathrm{B}$ is formed from a compound $\mathrm{A}: \mathrm{A} \rightarrow \mathrm{B}$. Differentiation of ( $\mathrm{r}$ a) gives:

and at $t=0, S_{t}=S_{\mathrm{o}}$.

$$
d S_{t} / d t=k\left(S_{f}-S_{t}\right)
$$

Some experiments performed by Bender ${ }^{2}$ on the work of disaggregation are shown in Fig. 7. These results can also be expressed by equation (ra), although not quite as closely as the previous ones. It would be of interest to study the ageing of snow as a function of temperature. The rate constant $k$ can probably be expressed by an exponential law, $k=A \exp (-E / R T)$, where $A$ and $E$ are constants, $R$ the gas constant, and $T$ the absolute temperature. An energy of activation $E$ could then be derived, which might throw some light on the ageing process. This ageing process has something to do with recrystallization, diffusion and sublimation in the contact areas between snow particles.

The great effect of the age of the snow from which they are made on the compressive strength of the cylinders of equal age is quite remarkable. This must be due to the metamorphism ${ }^{4}$ snow undergoes as it ages. New snow particles have numerous ramifications and protuberances, which are in an unstable state. Recrystallization, sublimation and surface migration take place rounding the particles. Thus the whole system tends to become more stable with age. Consequently, less bonding will take place on compression with old than with 
new snow. The strength of snow specimens as a function of the age of snow merits further study.

The decrease of compressive strength with decrease in particle size seems surprising at first. Microscopic examination shows that the snow passes from a more spherical shape to a more elongated one as the particle size decreases. It seems also to be the case that the smaller particles have less ramifications than the larger ones. One factor which might be of decisive importance in this connexion is the following. It was shown in Fig. 6 that the smaller the particle size, the higher the density obtained by just pouring the sample into the plastic cylinder. Probably less work of compaction is required to compress the finer particles to the same density than the larger ones. Therefore the larger particles will be under much more

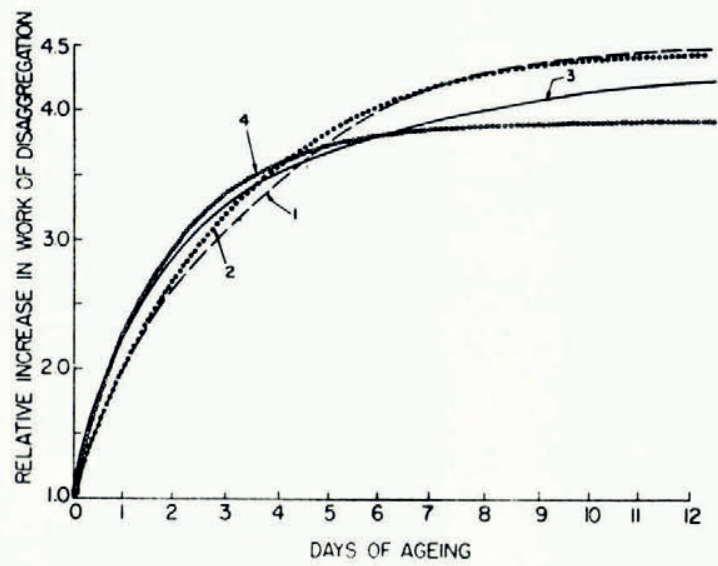

Fig. 7. Ratio of work of disaggregation at time $t$ to work at $t=0$ as a function of time. Curves $(1)$ and (2) are averaged experimental curves for $-5^{\circ} \mathrm{C}$. and $-20^{\circ} \mathrm{C}$. respectively. Curves $(3)$ and $(4)$ are calculated from equation $(1 a)$. Curve (3): $S_{0}=I \mathrm{~kg} . / \mathrm{cm}^{2}, S_{f}=3.9 \mathrm{~kg} . / \mathrm{cm}^{2}, k=5.6 \mathrm{I} \times 10^{-1} \mathrm{day}^{-1}$. Curve (4): $S_{0}=I \mathrm{~kg} . / \mathrm{cm}^{2}, S_{f}=4.5 \mathrm{~kg} . / \mathrm{cm} .^{2}, k=3 \cdot 31 \times I^{-1}$ day ${ }^{-1}$. Experimental results were obtained by Bender ${ }^{2}$

strain and stress than the smaller ones. In order to relieve this unstable condition, rearrangement has to take place, which leads to finer bonding. It would be of interest to carry out studies on fractions of differently shaped snow particles, such as spheres, needles, etc. A beginning has been made by Fuchs. 5 It would also be of interest to study snow cylinders by the replica technique developed by Fuchs. ${ }^{6}$ This would give an insight as to the number of bridges between snow particles as a function of specimen density, temperature, work of compression, etc.

The effect of gases, such as ammonia $\left(\mathrm{NH}_{3}\right)$ is not surprising. An exothermic reaction takes place forming $\mathrm{NH}_{4} \mathrm{OH}$. A concentrated solution is produced on the surface of the particles which serves as a lubricant for further compression. However, it does not seem possible to remove subsequently all of the $\mathrm{NH}_{4} \mathrm{OH}$ and $\left(\mathrm{NH}_{4}\right)_{2} \mathrm{CO}_{3}$ which is formed by absorption of $\mathrm{CO}_{2}$ from the air. Thus a film will be left between the snow particles weakening the whole structure. Experiments also show that for the same work of compression, the untreated snow still has a higher strength.

It is the author's pleasure to thank Mr. E. M. Schwarz for competent performance of the tests.

MS. received 24 July 19.58 


\section{REFERENGES}

1. Butkovich, T. R. Strength studies of high density snow. Snow, Ice and Permafrost Research Establishment, Research Report, 18, 1956, I9 p.

2. Bender, J. A. Testing of a compacted snow runway. Proceedings of the American Sociely of Civil Engineers, Journal of the Air Transport Division, Vol. 83, No. 1, 1957, p. 1324-1-1 324-20.

3. Butkovich, T. R. Ultimate strength of ice. Snow, Ice and Permafrost Research Establishment, Research Paper, 1 I,

1954, I2 p.
4. Bader, H. Mineralogical and structural characterization of snow and its metamorphism. In Snow and its metamorphism, chapter I. Snow, Ice and Permafrost Research Establishment, Translation 14, 1954, p. I-55. [Translated from Beiträge zur Geologie der Schweiz, Geotechnische Serie, Hydrologie, Lieferung 3, 1939.]

5. Fuchs, A. Schneeverfestigung. Schlussbericht, Teil II. Forschungsanstalt Graf Zeppelin (Stuttgart-Ruit), Bericht

Nr. 241, [c. I $94^{2}$ ?].
6. Fuchs, A. Preparation of plastic replicas and thin sections of snow. Snow, Ice and Permafrost Research Establishment, Technical Report, 41, 1956, 6 p. 